\title{
BIOECONOMY AND / OR BIOTECHNOLOGY: LIMITED IMPROVEMENTS IN TURKEY
}

\author{
İrfan Kalayc1 \\ Prof. Dr., Dep. of Economics, Inonu University, Malatya, Turkey
}

\author{
Ali Duran Uzun \\ Dr., Economist, Adana, Turkey
}

Hatice Özkurt

Lecturer, Istanbul University, Istanbul, Turkey

\begin{abstract}
Organic farming sector, on the way of sustainability and integration with bioeconomy, has some radical changes in the world. One of the causes for the emerging of bioeconomy is "selfsufficiency for food". Bioeconomy consists of bio-goods (energy, medicine, etc.) produced through existing and new technologies and processes. It can provide many environmental benefits like the decrease of greenhouse gas, the slow-down of global warming, biological variety etc. Biotechnology, considered as a part of bioeconomy, can be defined with four colors: Red (medical), blue (hydrologic), green (agricultural) and white (industrial). Today in OECD countries, $75 \%$ of the potential economic contribution of bio-technology has realized in agriculture and industry. In USA, EU and a lot of countries the number of bio-tech companies is gradually rising; and goods of these companies especially in supermarkets and pharmacies stimulate consumer demand and the endorsement of these companies is exceeding trillions of dollars. Turkey cannot turn away from this "bioeconomic revolution". Turkey still is not a competitive country in bioeconomy and biotechnology areas. So, Turkey should include bioeconomy investments in long-term development plans and strategies
\end{abstract}

Keywords: Bio-economy, Bio-technology, Sustainable Agriculture

JEL Codes: L69, O13, O31

\section{Bioeconomy, Agriculture and Sustainability}

G. Myrdal says; " agricultural sector is the only place that won or lost that fight for long-term economic development." In Such a war, there is "Bioeconomy" as well. Because, the age of the 21 st century, a finance and integration, is at the same time a "Bioeconomy" age. Bioeconomy; Turkey, like all the globalized economy, is closely related.

Bioeconomy is teeming with sustainability and the agricultural sector. The contemporary world and thus, structural agricultural policies of Turkey; Since 1990, has to take shape under the influence of Bioeconomy-Biotechnology science beginning to emerge as a synthesis of biology + farm + technology with the sustainability, which indexed almost every economic activity and hence also indexed agriculture. 
Here, OMAFRA (2012) mentioned "sustainability", according to the definition of Burtland Commission's 1987 in OECD, "to meet the needs of future generations without compromising their power to meet the needs of the present generation" means. The concept of sustainability multifunction (biological, techno-economic, socio-cultural) might be (Sundar, 2012).

\subsection{Bioeconomy : Conceptual / Theoretical Framework}

The term of bio-economy for the first time was defined by R.Martinez and J.Enriquez in 1997 the American Scientific Developments Association "Genomics" seminar. Enriquez and Martinez, published joint article "Biotechonomy 1.0: Rough Map of Biodata Flow" in the Harvard Business School, showed the global flow of genetic material. The authors, then, on production of bio-data stream and biotech patent licensing fees, established hypothesis in the context of economic influence on. One of the reasons the emergence Bioeconomy is 'food selfsufficiency / food security and furcating' and Guerrero's (2010) statement is a consequence of the globalization-induced food sector transformation and a manifesto. According to him, global food production and distribution, agricultural activity pulled 'aerodynamic' and 'neo-liberal' line and has become a standard under the cooperation and market paradigms, coordinated and classified.

According to UNSD (2012) Rio + 20 UNSD definition; bioeconomy is ecology, economic theory and practice to use ecologically and socially on the way of sustainable development. (Johnson, 2010), for the Bioeconomy, "the society's dependence on non-renewable resources to reduce significantly, the way to access vital source of carbon and energy' says. Deng (2010) expressed the bioeconomy, manufacturing models " $4 \mathrm{f}$ " (food, feed, fuel, fiber) will be changed to convert to the new agricultural development view. In this context, Mathews (2009) tells us there is a departure from petroekonomy to the Bioeconomy, as integrated with agriculture demand and to fossil fuel for constituting a serious option bioenergy production is said.

Bioeconomy, especially focused on goods and services linked to ecosystem and more sustainable than use of fossil fuels. Accordingly the European Commission (EC), Bioeconomy, as a product of the "oil-post" era, "while supplying input to food and feed, industry and energy production, an economy using of biological resources of the sea, soil and waste, as well as including biological form-based processes for sustainable industry " identified in shape is a realistic approach. (Hall, 2012)

\subsection{Birth grounds and Structural Properties of Bioeconomy}

The basic dynamic revealing Bioeconomy is needs and shortages. It is necessary to mention the dynamics depends on the following factors i-Water scarcity, fertilizer degradation, climate change issues such as new crops; ii-increasing world population (7,2 billion in 2014, 9,7 billion in 2050) nourishment obligation; iii-increasing calorie consumption per person (demand for meat will increase $70 \%$ in 2030); iv- reduce the use of agricultural areas, habitat expansion, environmental factors such as biodiversity conservation; v- security of supply, such as shifts in energy supply for $\mathrm{CO} 2$ reduction; vi- globalization and the variables affecting world trade as the EU Common Agricultural Policy (Lex, 2012).

According to Sundar (2012), the dynamics of biological systems that make up the infrastructure of life is affected by global socio-economic dynamics: Bioeconomy is required; to put in place 
chemical inputs in the production of goods and services processes, to produce biological pesticides and organic fertilizers, to apply organic farming and sustainable agriculture.

According to McDonald (2010), traditional agricultural economy, while addressing food and feed producers and the middle class; the agricultural economy of the future gives weight to bioproducts to continue the food and feed production in the axis of bioeconomy. Bioeconomy, covers bioproducts (biofuels, bio-energy, bio-materials are available, bio-medicine and bio cosmetics) the existing and new technologies and processes have been manufactured by from renewable sources.

Writers emphasized (Hipple, et al., 2007) bioeconomy provides "potential benefit". Biodiesel, electricity; wind, solar, water and energy derived from geothermal systems; energy efficient technologies; industrial products from the soil and forest resources, etc. Nationally, Bioeconomy can reduce oil imports, high oil costs, price volatility, foreign trade deficit. In addition, by the way reduced goods support, it can improve the WTO's blue and green box payments balance and by the way carbon credits and green payments can increase wealth $t$, too. A strong bio-economy may also provide environmental benefits such as life on the quality of air and water environment, new products not creating pollution, reduction of greenhouse gases, alleviation of climate change, protection of wildlife, biodiversity, better use of fertilizers, On the other hand, according to the same authors, Bioeconomy carries some strong "potential risks" too: for example, comfort ethanol's rapid demand growth may have an adverse results in the effects on seed prices, food and feed availability, environmental impacts and rural communities.

Part of Bioeconomy or partially biotechnology considered its identical, as are colorful activities. As proposed by the European Congress of Biotechnology; basically red (medical), blue (hydrological), green (agricultural) and white (industrial) form consists of four subsections, which are addressed in all areas of life with this structure.(see fig 1)

\begin{tabular}{|l|l|}
\hline $\begin{array}{l}\text { (I) Focused on medical applications } \\
\text { "Red biotechnology" }\end{array}$ & (II) Water-based products "Blue biotechnology" \\
\hline $\begin{array}{l}\text { (III) Agricultural applications oriented "Green } \\
\text { biotechnology" }\end{array}$ & $\begin{array}{l}\text { (IV) Industrial applications oriented "White } \\
\text { biotechnology" }\end{array}$ \\
\hline
\end{tabular}

Figure 1. Coloured Activities in Bioeconomy

According to OECD (2009) biotechnology is to improve human health, to create environmental change and has the power to expand the world of business volume. Because, for example, biotech drugs provide more health superiority of the traditional type. Until now modern biotechnology performing (DNA, viruses, bacteria, vitamins, etc. in area) a number of applications and the invention has been proven this. With the today's structure and development line of biotechnology, as its share less tan $1 \%$ in GDP in OECD countries, is estimated that its ratio will reach up to $3 \%$ by 2030 . despite the realization of the potential economic contribution of biotechnology in the OECD area, 75\% in agriculture and industry, biotechnology company only $6 \%$ of $\mathrm{R} \& \mathrm{D}$ expenditures related to these two sectors today. Meanwhile, $85 \%$ of current operating expenditure for biotechnology R \& D is transferred to the health sector; $25 \%$ of this is potential recyclable $(\mathrm{OECD}, 2010)$.

According to the organization (Biotechnology, 2009) Mendel; ' the convergence of agriculture, energy and biotechnology, is preparing the base for the entrance of new Bioeconomy in many rural areas in need of economic development ". Accordingly, only the creation of total business 
from renewable fuels area is under project 100 for 2012, more than 800 thousand for 2022 . While direct economic output in 2012 is 5,5 billion \$, it will be envisioned increasing to 37 billion $\$$ in 2022. Moreover, according to (Iglesias, 2005) the Bioeconomy includes that agriculture, food, forestry, fishing etc. producing biological resources, managing, and using all industries and comprising economic sectors, has reached total $€ 1.5$ billion turnover each year in Europe.

\subsection{Bioeconomy, and Organic Agriculture}

While Sustainable agriculture-Bioeconomy vision being drawn, it has come to the agenda of organic farming and GMO issue. Organic or biological farming is an agricultural system emerged as an option against negative consequences of human health, the economy and the environment based on the use of high input industrial agriculture. In the global organic markets, US, West Europe and Swithzerland is seen to be raced.

The food consumers to act pragmatically against GMOs; new Bioeconomy, which declared war on the old production technology, which continuously new discoveries in molecular and cell biology, and which offered blessing of the new bioenergy production, noted to be effective in this behavior (Wesseler \& Aerni, 2011; Wesseler and Aerni 2011a) .

One of the expectations in this regard is: Supermarkets; will continue to offer the option organic food (OF), non-organic food (NOF) and GMO in the form of food and perhaps supermarkets will vary OF, NOF and GMO's supermarket in shape. Some supermarkets will be able to create an awareness or compete against rivals such as " Here can not be sold GMO crops " or " Here are sold only GMO products " by hanging sign.

\section{Bioeconomic-Biotechnological Developments in World}

According to OECD (2009; 2009a) 2005-6 data; in Europe and the United States, 3300 units biotechnology (biotech) company is active, partial biotech company is 2075 units in the EU, 2744 units in the USA. If a comparison to be made; EU biotech companies are 6 times less profitable than in the United States', 3 times less than the average worker, companies that are 6 times less R \& D investment. In field of Bioeconomy-biotechnology, in the field of biotechnology R \& D while USA make more than 3 times investment Europe; 2001-5 period, China, making investment $€ 1,1$ billion (12 billion yuan) has been estimated to invest over 2 times in the next period.

Bioeconomy is the sector of the future as well. According to OECD $(2009 ; 2009 \mathrm{~b})$ "Biotechnology 2030" the report; three major sectors; Bioeconomy in 2030, 39\% of industrial biotechnology, $36 \%$ of primary production biotechnologies (agriculture, forestry, marine); $25 \%$ will create health biotechnologies.

\subsection{European Union: Bioeconomic Integration}

We are faced with a bioeconomic EU. Because, according to Aguilar (2006) and CORDIS (2012) account; Bioeconomy, mainly agricultural and chemical industry, employing 22 million people in Europe and $€ 1.5$ trillion as based on annual investment, is a giant industry. Updating these data; the European Bioeconomy, as the industry of the future, from now, in exchange for the use of the excess of $80 \%$ of agricultural land (for the production of plants, animals, fish, 
forest), promises annualy a 2 trillion $€$ turnover and corresponding to $9 \%$ of the total EU labor to employ 22 million people (EC-CSWD, 2012: 5).

Accumulation of the agricultural has strong role in The EU having such a large sector. According to The European Commission's 2008 data and the 7th Framework Program (FP) the guide; Within the borders of the EU (EU-27); The total land area is 420 million ha. and its 43\% use for agricultural production, its $40 \%$ is forestry and its $5 \%$ has more biofuels reserve; corresponds to $7.6 \%$ of total employment is 17 million farmers which are working; it is made of $13 \%$ of world cereal production; forest sector constitutes $8 \%$ of the EU manufacturing sector and employs around 3-4 million industrial workers; compared to 5\% of GDP is based on water resources and share of agriculture is 3.5\% to the gross value added; Demand for food will increase $70 \%$ by 2050 ; EU agriculture, (regardless of forestry) with a 76 billion $€$ value, while constituting of the $18 \%$ of the world's food exports, provides more than $40 \%$ the total OECD food production (Eurostat, 2008; EC, 2012; EC-European Bioeconomy, 2012).

EU Bioeconomy industry is estimated at $€ 2$ trillion annual turnover. Bioeconomy strategy is three-pronged: (1) research, innovation ("R \& I") and the ability to invest in developing new technologies and processes; (2) advancing markets and competition in bioeconomic sectors; (3) closer and more regular work with policy makers and stakeholders. Every 1 euro invested for R\&I in EU Bioeconomy assumed that it will have created $€ 10$ added value in bioeconomic sectors by 2025 . For example, bio-waste can be considered as potential at bioenergy conversion and can meet $2 \%$ of the EU's renewable energy target (Sheridan \& N.Beckett, 2012; EC, 2012). (See also Table 1.)

Table 1. A cornerstone of the EU economy: Bio-economy (2010)

\begin{tabular}{|l|c|l|}
\hline Sub-sector & $\begin{array}{c}\text { Annual turnover } \\
\text { (€ billion) }\end{array}$ & Employment ('000) \\
\hline Food & 965 & 4,400 \\
\hline Agriculture & 381 & 12,000 \\
\hline Paper & 375 & 1,800 \\
\hline Forest & 269 & 3,000 \\
\hline Fish and fishery products & 32 & 500 \\
\hline Bio-based industries & $56,8(\mathrm{t})$ & $355(\mathrm{t})$ \\
\hline Total & 2,078 & $22,005(*)$ \\
\hline
\end{tabular}

Source: KBBE in Europe, 2010 ve EC Facts and Figures, 2010 quoted from; Vassarotti, 2011: 6.

(*) Equivalent to $9 \%$ of total employment.

FP7 (207-13), one of the Europe Commission's civil R \& D programs, is an important scientific projects package. FP7's based on "cooperation" the second of the 9 thematic priorities (after health) is "Food, agriculture and biotechnology". Unlike many other Community Programme FP7 is the highest budget, entirely based on international competitiveness and scientific excellence. The object of FP7 which consists from four chapters and $€ 53.2$ billion is to to ensure European leadership in many key areas by cooperation with the the EU Member States, candidate countries and international organizations. Topic with "Cooperation private program" section's total budget is 32.4 billion $€$ and its section of 1.93 billion $€$ is is devoted to the field for "food, agriculture, fisheries and biotechnology" (TÜBİTAK, 2010; TÜBİTAK AB Çerçeve Proğramları, 2010).

According to the Bio-economy Council's estimates; based on Bio economic sector of the annual avarege turnover in Europe is $€ 1.7$ billion and employs 22 million people. 1 of every 10 jobs 
in Germany is related to the agriculture and food industries. In agriculture, in 370 thousand companies the full / part-time workers about 1.25 million persons makes each year $€ 40$ billion worth of production. More than 100 thousand workers are active in the field of bioenergy, provides 11.4 billion $€$ turnover which equivalent to $34 \%$ of all renewable energy (BMBF, 2011:10).

The distribution of the bio-tech companies are as follows: medical diagnosis and treatment in the EU $55 \%$, services $34 \%$ and $11 \%$ of agri-environment; USA respectively $64 \%, 31 \%, 5 \%$. Europe is still ahead in terms of increase in biotech companies.

\subsection{USA: Bioeconomic Revolution}

Bioeconomy is referred to as a revolution in American agriculture. US-based National Agricultural Biotechnology Council proclaims, while the 21st century declared Bioeconomy age, Bioeconomy's; i-renewable resources would make the sector more sustainable by using the internal dynamics; ii- Bio-based costs play a leading role through $\mathrm{R} \& \mathrm{D}$ to reduce against fossil-based energy and products; iii- to reduce the effects of climate change depend on $\mathrm{CO} 2$ greenhouse gases; iv- to creat rural-urban business opportunities in agricultural and the industrial sector; v- to increse the quality of air, water and fertilizers; vi- to improve the food health for human and animal; vii- Owing to reducing oil imports of countries, affects favor in balance of payments. (NABC, 1998: 1)

In addition according to Posel (2012) in the context of the vision of the United States in 2030, the Obama administration under genetic engineering specifically supporting in the biopreferred programs axis, genetic modified organisms (GMOs) will fill consumer markets, it will be investigated the medical technology based on Bio, the companies that produce renewable energy from farm animals will be kept on hand, rural areas in accordance with sustainable agricultural practices will be nationalized by the government, which is notified.

\subsection{Others}

Bioeconomy world does not consist only of the EU and the US. In other countries are also made investments within the plan-programs in this field.

-Germany: EU locomotive engineer of one of the two in Germany, Bioeconomy parallel to usually rising to a peak of science and exports is developing very fast. According to 2011 data, around 500 biotech company is active, which its $83 \%$ is developed in medical-axis as "red biotechnology". Companies working in the animal health and industry and is over $1 / 3$ of total.

- China: China's agricultural infrastructure appears consistent with bioekeconomy and is rapidly developing. The more country develops technological base, the more it also increases the potential of the field in Bioeconomy. This' proof is biofuels industrial gained large scale with many ethanol plants.

- Sweden: A successful example of bioeconomic solution is Linköping, Sweden. Local pollution has decreased by passing from diesel buses to gas alternative-fuel fleet to in 140 thousand people city. City management are pioneers of bioeconomic establishing biogas plant with biogas companies, local butchers, farmers union. While Economic sectors related to the Bioeconomy have supplied $14 \%$ of the country's GDP, also realized at $13 \%$ of total employment.

- Denmark: Denmark, in recent decades, in Kalundborg with the successful example of "ecoindustrial park", has given inspiration to the the industrial ecologist. The exchange made in the 
area of inorganic materials and energy is a good reference point on this issue because it creates an instance of the successful organization closed material and energy cycle.

- Belgium: Energy production and farming completed, one of the remarkable examples of industrial eco-parks are also located in Belgium. In 2009, a 9 MW power plant was built by a Finnish company near Merksplas in an agricultural land and can be operated by filling with different liquid biofuels. Heat produced in the factory, is also used for agricultural operations as meet local electricity needs. The efficiency of all solutions was measured as greater than 85 percent.

- Finland: Finland, knowledge-oriented and biofuel production which is quite convenient localized Bioeconomy to become a leader in the country, has all the advantages. But the current business structure in the production and consumption of bioproducts and management is a serious obstacle. Because the competitive aspect of the biofuel plant is weak. Fin Bioeconomy has already come to the advanced level in subject of which the operation of waste, the converted value added by using in energy and agriculture again.

\subsection{In the future (2025 and 2050 right) Global Bioeconomy}

Burel (2012) while revealing the 2025 vision, notified that many chemical products and materials would be produced by passing one or more step from biotechnology and biotechnology provides possibility that ecological-effective use of renewable resources such as industrial raw materials. According to his estimates: -depending on economic relevance- rural biorefinery will take place of oil refinery; industrial ('white') biotechnology will provide opportunities to industries which will manufacture in a sustainable way as economic and environmentally; agricultural ('green') biotechnology will also make a significant contribution in the efficient production of bio-fuel raw material and based on this framework will have represented an increasing share of biotechnology-derived biofuel energy in the European energy consumption.

OECD (2012) presented reports to the world public opinion, while ranking external factors that will lead to Bioeconomy to the 2030, stressed that the biggest factors are particularly developing the growing population in the country and falling per capita income: i-GDP will grow $2.3 \%$ in the OECD and it will annually grow by $4.6 \%$ in developing countries. Naturally, this trend makes Bioeconomy and biotechnologic markets incentive is inevitable. ii- Inside OECD and outside OECD, contribution to the GDP of the biotechnology -as weighted agriculture and industry- will be able to reach average $2.7 \%$ in 2030. iii- in food genetically modified (genetically modified, GM) production will be an explosion. iv- while the ratio of biochemical products to the total chemical products in 2005 is $1.8 \%$, in 2015 between $12 \%$ to $15 \%$, and in 2030 will rise to $35 \%$; In 2030, the proportion of agricultural products produced by biotechnology is expected to reach $50 \%$.

The FAO said that 21st century will pass with multiple challenges, of the world's rising population will make the food and fresh water needs increase around $70 \%$ in 2050 , need for about 2.2 million ha new agricultural areas, but the report has notified to be wasted about $60 \%$ of irrigated agriculture(Albrecht, et al., 2010). In this context Pilzecker (2011) would emphasize that it is mandatory to bioeconomic production and consumption in our world $70 \%$ of the demand for food and energy demand will increase 2 times levels and global warming will be at $+2{ }^{\circ} \mathrm{C}$ until 2050 .

\section{The Bioeconomy-Biotech Vision of Turkey}


What is the Turkey Bioeconomy site? In this field whether will be a "player" or stay "audience" in the bleachers? Turkey's population, according to demographic projections, in 2050 to reach 100 million people. Then the state to feed the citizens prosperous food and agricultural resource management must be planned in advance. Agricultural Bioeconomy exhibits vital at this point.

Main problematic is this: "What is the status of Bioeconomy in Turkey?" " Where is Turkey located in the Bioeconomy?" "Bioeconomy, what sense does it mean for Turkey as part of sustainable agriculture concept?" Questions can be replicated, but one of the most common answer to that is this; Turkey, like every modern country, knows potential food shortages and increased biofuels production prove the importance of agricultural products, but also that environmental pollution and global warming affected the interests in bio process and biological waste. In Turkey, with seventh Development Plan established by the Special Commission of Biotechnology created, has been started officially attention this issue. However, biotechnology's not sufficiently in the "National Science, Technology and Innovation Strategy 2011-2016" prepared by TUBITAK has reduced the visibility of this interest.

According to Çiftçi's (2008) detection; Turkey, due to leaping for oil and fossil fuel prices, with purposed lighting activate renewable based on Bio fuels and Bioeconomy field as an indication that you have a better chance in global competition, $20 \%$ of the world's yeast produces alone. Also: Turkey wants to be a global-good player in Bioeconomy. For this, in axis of R \& D has started to record the following developments: i- Turkey is rapidly increasing its R \& D budget to achieve the EU average. ii- Turkey has got share from EU 6th and 7th Framework Programme. iii- Turkey's universities and science parks, owned more than 20 biotechnology engineering, more than 30 food engineering, more than 20 agricultural engineering, more than 10 Forestry and Fisheries Engineering and more than 50 biology department, are developing. iv- agricultural growth, output and export potential is increasing rapidly.

Bioeconomy and biotechnology which its special branch or appearing face is new in the world, the number of countries to build up statistical data showing progress in this area is extremely small. Biotechnological development level; should be dealt with the ratio of R \& D and innovation-entrepreneurship opportunities and so on. Western economies at the beginning of that generous R \& D spending comes in Biotechnology: according to 2011 data; Finland, Sweden, Israel and Switzerland, Taiwan, Denmark, Japan, 7-8\%; USA, Canada and West Europe 5-6 \%; BRICS and Turkey 2-3 \% (SAWV, 2012).

Of a science magazine originated United States, to give an idea of biotechnology development, if the report is seen taking total point (between 0-10 per category) from each country's 6 categories (innovation performance, enterprise's support, capital-information density, education, institutions, policies and stability); USA is the first by 38 points, while Indonesia is 50th by 9 points, Turkey is settled in 42 nd by 14.99 points coming before Mexico and China (SAWV, 2012).

According to identify of Yardımc1 (2012) investigating the development of biyoeteknoloj in Turkey: i-still the world's biotech market size is $48 \%$ owned by the US, is reached 318.4 billion dollars in 2014. Biotechnology applications in the health sector concentrated in Turkey, according to 2010 figures, has already created approximately a $\$ 1.7$ billion market size. i- In the study reports of Vision 2023 Strategy Paper; statement, " Biotechnology identified as 21. century technology, not only limited improving the quality of life of our people, but also gain the economic and technological superiority ", is located. The effects of synergy which will gain 
particularly with the success achieved by the application of biotechnological applications in the agricultural sector would be much greater than has been assumed.

Despite all this work, according to a study including 48 countries by Scientific American; Turkey, in terms of generation capacity in biotechnology innovation, is located in 39th (first three rows are USA, Denmark and Sweden). Turkey, lined with superior economy on biotechnology in a 34-country world league, is located at the end after S. Africa Republic (Figure 2).

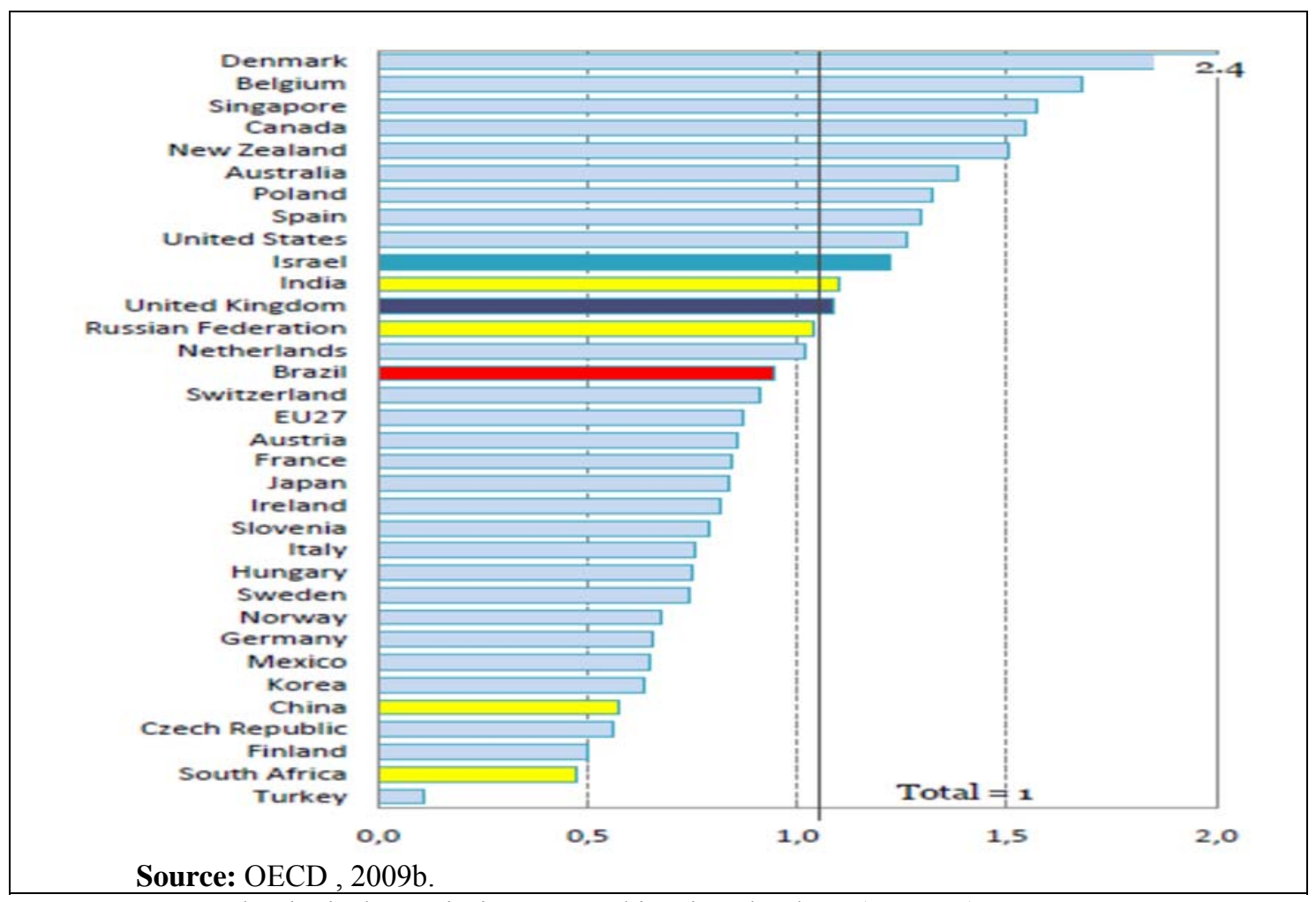

Figure 2. Technological superiority appeared in Biotechnology (2004-06)

While determining where Turkey's biotechnology in the world, patent applications should be noted that there is little or no (Figure 3). 


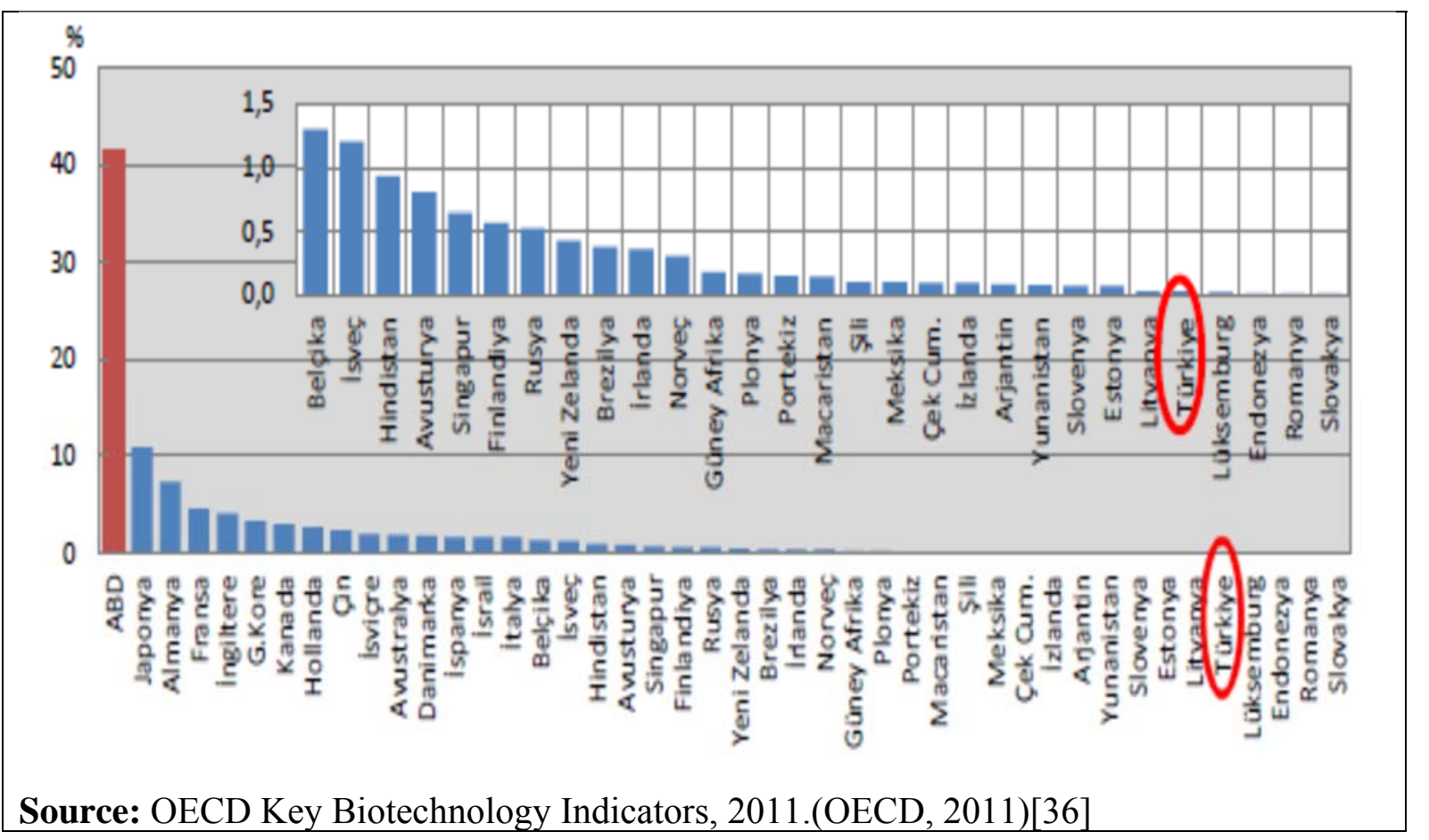

Figure 3. Distribution of the countries of the world biotechnology patent (\%), 2007-09.

Turkey's agricultural structure transformation basing our analysis on the relationship between the biotechnology in as stated in the report: Biotechnological methods began to be used widely to increase agricultural production. Will further expand the application fields. In general biotechnological methods; can be considered as plant tissue culture techniques, molecular breeding methods and genetic transformation methods. There is no a widespread use of agricultural biotechnology in Turkey. The first plant tissue culture laboratory was established in 1974 but has not been sufficient to meet demand. (DPT, 2004)

Thanks to its huge potential in Turkey's agriculture sector will be a major industrial biotechnology players, especially the "white biotechnology" in the form of a huge economic growth opportunities, it is a proof of that today $20 \%$ of Turkey's world yeast They think that to produce alone. According to them, the state's expected to make arrangements to promote innovation in biotechnology and mass production and to create a variety of standards. (SusChem \& etc, 2009)

\section{Conclusion: Recommendations}

Turkey, as "geo-strategy" as "bio-strategy" / "eco-strategy", "Bioeconomy-strategy' should also be cared for. Because one can not substitute for the other.

On the way prevention of agricultural waste, easy access to renewable resources and the growth of prosperous society, university should open Bioeconomy programs, government should develop biopolitics, industrial sector should increase biotechnological R \& D budgets, our agricultural sector should be more brave to organic farming.

In the name of the rapid industrialization if Turkey sacrifices agriculture to industry, like a disease, "Japanese syndrome" (the JS) can be captured. For not catching JS vortex (until now from 1950, in order to self-sufficiency, that industrial countries particularly Japan import $70 \%$ of grain) grain stocks should be planned as "economic" and should not be wasted like 5 star 
hotel running the"buffet" system. Because; there is also lost the stars one by one due to huge waste.

"Gene Bank" entering the field of biotechnology newly and branching out should be established to make seed diversity and richness sustainable. Turkey has already begun work in this direction for sometime. According to S.Y1lmaz President of West Mediterranean Agricultural Research Institute noted; i- Apart from a center that can accommodate 86 thousand seeds in Institutes, Gene Bank (Ankara), contains a combination of to 250 thousand seeds, was established inside the Ministry of Agriculture. ii- Turkey, importing of these seeds almost all before, today has come to the point to export to the world around 40 seeds. A garden which combines 500 varieties has been established, it grows about 300 varieties. iii- 103 varities of seeds in many fruits and vegetables in the last 6 years and also 20 varieties of corn, 4 varieties of soybeans, were registered.

Bioeconomy and/or biotechnology should be created an economic development strategy focused on and should be implemented. Also, the "ecological literacy" or with an assortment of "Bioeconomy literacy" training seminars should be expanded. Thus, consumption of natural resources of the community, the danger of hunger and thirst, pollution of soil and even to raise awareness about global warming may increase.

\section{References}

Aguilar, A., 2006. European Knowledge-Based Bio-Economy: Food, Agriculture and Biotechnology. Helsinki, European Commission.

Albrecht, J., Carrez, D. \& Cunningham, P. e., 2010. The Knowledge Based Bio-Economy (KBBE) in Europe: Achievements and Challenges, s.l.: Ireland European CommissionEuropena Research Area.

Biotechnology, M., 2009. Opportunities in the New Bioeconomy.

BMBF, F. M. o. E. a. R., 2011. National Research Strategy BioEconomy 2030 Our Route towards a biobased economy, Berlin: s.n.

Burel, C., 2012. Industrial or White Biotechnology: Research for Europe, EuropaBio, Brussels: Secretariat of the SusChem IB Section.

CORDIS, 2012. The Knowledge Based Bio-economy (KBBE) and Industrial Biotechnology. s.1.: European Commission, DG Research, Directorate Food, Agriculture and Biotechnology..

Çiftçi, T., 2008. Bioekonomide İnovasyonun Ticarileşmesi.

Deng, X., 2010. Development of the Concept 'Bioeconomy.

DPT (Devlet Planlama Teşkilatı), 2004. Türkiye İktisat Kongresi Çalışma Grubu Raporları II: Tarımsal Yapıda Dönüşüm Çalışma Grubu Raporu. s.1.: TZOB (Koord.).

EC-CSWD, 2012. Accompanying the document Communication on Innovating for Sustainable Growth: A Bioeconomy for Europe. Brussel. 
EC (European Commission), 2012. Commission proposes strategy for sustainable bioeconomy in Europe. Brussels: European Commission Press Release.

EC, 2012. Sustainable Agriculture and Forestry: EC-European Bioeconomy.

Eurostat, 2008. EU agriculture, forestry and fishery facts and figures. s.1.:s.n.

Guerrero, B., 2010. Globalization, and Food Crisis Discourse. s.1.: School of Labor and Industrial Relations University of the Philippines- Atlantic Community.

Hall, R., 2012. Bio-economy versus Biodiversity. Global Forest Coalition.

Hipple, Auburn, J. \& R.Hedberg, 2007. The Human and Social Dimensions of a Bioeconomy: Implications for Rural People and Places. s.1.: USDA—CSREES.

Iglesias, M., 2005. Rural development in a Knowledge-based bioeconomy, Brussels: Directorate Biotechnology, Agriculture and Food European Commission - DG Research eRural.

Johnson, L., 2010. The Bioeconomy-A Revolution in American Agriculture. s.1.: Iowa State University Center for Crops Utilization Research.

Lex, M., 2012. The Knowledge Based Bio-economy (KBBE) and Industrial Biotechnology. s.1.: European Commission DG Research Directorate Food, Agriculture and Biotechnology.

Mathews, J., 2009. From the petroeconomy to the bioeconomy: Integrating bioenergy production with agricultural demands. 3(6).

McDonald, I., 2010. Agricultural/Forestry Opportunities in the Bioeconomy with BiomassApplied Research Coordinator.

McDonald, I. 2010. Agricultural/Forestry Opportunities in the Bioeconomy with BiomassApplied Research Coordinator, Ontario Ministry of Agriculture, food and Rural Affairs.

NABC (National Agricultural Biotechnology Council), 1998. National Agricultural Biotechnology Council, Vision Statement: Vision for Agricultural Research and Development in the 21 th Century.

OECD (The Organisation for Economic Co-operation and Development), 2009. OECD Biotechnology Statistics 2009, Paris: OECD.

OECD, 2009. The Bioeconomy to 2030: Designing a Policy Agenda, Paris: OECD.

OECD, 2010. Agricultural Transformation, Growth and Poverty Reduction, Bamako, Mali: China-DAC Study Group.

OECD, 2011. Key Biotechnology Indicators. 
OECD, 2012. The Bioeconomy to 2030: designing a policy agenda, International Futures Programme.

OMAFRA (Ontario Ministry of Agriculture, Food and Rural Affairs), 2012. Bioeconomy Industrial Uses, Strategic Research Themes - Priorities for 2008-2012.

Pilzecker, A., 2011. Biomass in the new Common Agricultural Policy: Biorefinery Project Networking Event. Brussels: European Commission (Directorate-General for Agriculture).

Posel, S., 2012. Obama's Bioeconomy Promotes a Genetically Engineered Future. s.1.: Occupy Corporatism.

SAWV, 2012. A Global Biotechnology Perspective. .

Sheridan, P. \& N.Beckett, O. Q., 2012. European Union: The EU and Its $€ 2$ Trillion Bioeconomy Introduction.

Sundar, İ., 2012. Bioeconomics and Sustainable Development. Dubai, International Conference on Management, Applied and Social Sciences (ICMASS'2012).

SusChem, S. C. \& etc, 2009.

TÜBİTAK (Türkiye Bilimsel ve Teknolojik Araştırma Kurumu), 2012. AB 7.Çerçeve Proğramı Genel Bilgi.

TÜBİTAK, 2010. AB Çerçeve Proğramları.

UNSD, 2012. Bio-economy and development: Beyond the crisis, another world. s.l.: Organizing partners Cobase Basic Technical Scientific Cooperative.

Wesseler, J. \& Aerni, P., 2011. Wesseler, Sustainability and the bioeconomy. 14(3). 